\title{
Concentration-Dispersal Strategies to Assist Geotourism Destination Planning: A Case Study of Ciletuh-Palabuhanratu UNESCO Global Geopark
}

\author{
Shandra Rama Panji Wulung ${ }^{1 *}$, Rifki Rahmanda Putra², Raden Willy Ananta Permadi² \\ Muhammad Iqbal Maulana² \\ ${ }^{1}$ Indonesia University of Education, Bandung, Indonesia \\ ${ }^{2}$ Padjadjaran University, Bandung, Indonesia
}

\begin{abstract}
This article aims to identify and design a spatial model of geotourism destinations based on concentration and dispersal strategies in Cisolok Geoarea, Ciletuh-Palabuhanratu UNESCO Global Geopark, Indonesia. This study uses a qualitative approach with primary and secondary data collection. Primary data collection was carried out through field observations at the Cisolok Geoarea and semi-structured interviews with people directly involved in the development of the Ciletuh-Palabuhanratu UNESCO Global Geopark. The positioning of spatial elements based on satellites uses the Global Positioning System (GPS) technology. In the meantime, secondary data carried out through literature studies on policy documents, planning, and previous research. The analytical method used in this study includes qualitative analysis, map analysis, and descriptive analysis. Stages of research were carried out through the process of input, management, plotting, and conversion of data and information obtained. This study found that Cisolok qualified as a geotourism destination with the support of eleven integrated spatial elements. The results of this study can be a strategy for the dispersal of tourists visiting the Ciletuh-Palabuhanratu UNESCO Global Geopark, especially in Cisolok Geoarea.
\end{abstract}

Keywords: Ciletuh-Palabuhanratu UNESCO Global Geopark, destination management, geotourism, tourism planning.

\section{INTRODUCTION}

Geotourism destinations, also known as Geoparks [1,2], have the opportunity to develop sustainable areas [3]. Geopark contributes to promoting awareness of geological features (conservation, information, and education) and geological resources (geotourism and sustainable development) by involving community participation [4,5]. Geopark empowers local communities and provides them with opportunities to develop joint partnerships that are driven by geotourism through regional investment, create business opportunities, new jobs, and generate financial benefits for the local community [6]. Through tourist visits, geopark has a role in regional economic development. Tourist trips to the geopark encourage economic movement in the same direction [7], benefiting all people in the geopark region and contributing to sustainable regional development $[8,9]$. Besides, geotourism activities have the potential to damage the natural environment due to the uncontrolled carrying capacity of tourist attractions, and that is a challenge in developing sustainable geotourism destinations [10].

Correspondence address:

Shandra Rama Panji Wulung

Email : wulung@upi.edu

Address: Jl. Dr. Setiabudhi No.229 Bandung 40154 Indonesia
Ciletuh-Palabuhanratu region has the potential as a geotourism destination [11]. The designation of the Ciletuh-Palabuhanratu region as one of the UNESCO Global Geoparks (UGG) provides opportunities for sustainable regional development through the development of geotourism, particularly in Cisolok Geoarea. Cisolok Geoarea has a geodiversity, biodiversity, and cultural diversity that has become a tourist attraction before the geopark [12]. To stimulate the development of geotourism requires planning of geotourism destinations in the Cisolok Geoarea, Ciletuh-Palabuhanratu UGG. Tourists need to find relevant information on Ciletuh-Palabuhanratu UGG [13], including information on tourist attractions, accommodations, accessibility, and activities. The concentration of facilities and services for tourists plays a role in minimizing the potential negative impacts on the socio-cultural environment and minimizing the cost of developing infrastructure, thereby offering opportunities to make destinations more attractive [14]. Concentrated tourism activities play a role in facilitating the flow of tourist visits, goods, and services to and within tourism destinations [15]. On the other hand, the dispersal of tourists from concentrated areas provides opportunities to distribute work and benefit income equally $[14,16]$. The combined strategy of concentration and dispersal becomes 
an effective strategy for sustainable regional development [17].

Previous research explained that the dispersal strategy in tourism destinations is needed to disperse tourists from the main tourist concentration center to reduce pressure on the core area. Destination management organizations (DMO) in Europe have succeeded in spreading a large number of tourists from vulnerable sites to other tourist attractions. It proves that dispersal strategies can reduce the negative impact on vulnerable tourist attractions [18]. In the Maldives, DMOs tend to prefer not to develop tourism destinations in residential areas to minimize disruption to established socioeconomic structures [19]. Tourism Development in Mexico is another example of successfully implementing a concentration-dispersal strategy by developing a staging area on a remote island (Cancun Island). It succeeded in making the island a leading tourism destination that brings in 2 million tourists every year [20,21,22]. Previous research and best practice examples showed the importance of studies related to the dispersalconcentration strategy, because it plays a role in reducing pressure on core areas in tourism destinations, triggering dissemination of socioeconomic impacts, increasing length of stay and total tourist expenditure, and increasing the attractiveness of tourism destinations through offering new tourist attractions for tourists.

The difference between this study and previous research is the scope of the study. This research is focused on the design of spatial models for geotourism or geopark destinations; no previous studies have designed or applied concentration-dispersal strategies in geoparks. Furthermore, in Indonesia, there has never been any research related to concentration-dispersal strategies, both in tourism destinations and geoparks. This article seeks to analyze geotourism destinations through a combination of concentration and dispersal strategies at Ciletuh-Palabuhanratu UGG, particularly in the Cisolok Geoarea. This study aims to identify and design a spatial model of geotourism destinations based on a concentration-dispersion hybrid strategy and implement it in the Cisolok Geoarea.

\section{Concentration-Dispersal Hybrid Strategies}

The development of unregulated geotourism destinations tends to have concentrated spatial patterns and indicate them as unsustainable tourism destinations. The role of appropriate regulation and management in the concentration of tourism activities has a function as an effective strategy and contributes to the achievement of sustainable tourism destinations $[16,23]$. Concentrated tourism activities contribute to limiting negative impacts and facilitating visitor management. A concentration strategy means controlled and integrated planning and development [17].

The strategy of concentration in geotourism destinations can be implemented through concentrating tourist services and grouping tourist attractions. The tourist service center, or staging area [14], is an area specifically designated for meeting the needs of tourists in geotourism destinations, including accommodation, tourist information centers, shopping centers, souvenirs, and other tourism support facilities. The grouping of tourist attractions provides destination competitiveness, attracts more and increases tourists' length of stay, provides efficient transportation and infrastructure access, provides comfort for tourists, easily accessible tourist facilities and services, and minimizes the impact of tourism activities [14,17,24]. The involvement and capacity building of local communities is certainly no less important to support sustainable regional development. To accommodate the function between conservation and tourism, local community involvement is needed in the development of geotourism destinations [10].

The concentration strategy is related to the dispersal strategy in supporting sustainable tourism destinations. Dispersal strategy is an effort to distribute tourists from concentrated service centers to reduce pressure on the area of tourist service centers or settlements, spread tourism revenue, and increasing the competitiveness of destinations through exploration and introducing secondary tourist attractions or new characteristics to tourists. Dispersal strategies mean distributing tourism activities to support employment and income equality on a national, regional, local, and specific scale [16].

\section{Geopark as a Geotourism Destination}

Integration between aspects of geodiversity, biodiversity, and cultural diversity has the potential to support the development of geoparks as pioneers and innovative strategies for nature conservation, land use planning, and sustainable regional development [25]. The geographical approach is needed in planning 
more comprehensive geotourism destinations between geological (abiotic), flora and fauna (biotic) elements, and the presence of local communities (cultural) [6]. It follows the concept of the geopark, which is a geographically integrated area with significant international sites and geological landscapes and is managed holistically as an effort to support environmental protection, education, and sustainable development [13].

Geotourism destination planning is related to the concept of the tourism system. The relationship between the existence of space and time elements that empirically explain the pattern and function of tourism destinations through the relationship between tourist behavior and destination structure [26]. There are previous studies relating to the planning of geotourism destinations in various regions, including Varkala Geopak, India [27]; Caldera Toba Geopark, Indonesia [28,29]; Langkawi Geopark, Malaysia [30,31]; Dong Van Karst Plateau Geopark, Vietnam [32]; North Kalimantan, Indonesia [33,34]; Jeju Geopark, South Korea [35, 36]; Bandung Basin Region [3739]; and Bromo-Tengger-Semeru-Arjuno Biosphere Reserve [10]. There are five basic principles to consider in designing geotourism destinations through spatial models [15].

1. The destination physical characteristics. Travel patterns are closely related to physical characteristics, such as availability of access, costs incurred, distance and travel time, and route conditions between tourist attraction locations.

2. Tourism destination study, the character of each tourism destination has a different structure, so the planning model must adjust to the conditions of the study area.

3. Functional and normative. The integration of local regulations and the empirical conditions of spatial planning can influence tourism destination planning.

4. Explanatory and predictive. Explaining the actual conditions and can predict future market developments.

5. The integration of spatial elements, nature, and the relationship between the tourism components, including nodes, paths, and networks, becomes crucial in planning a model of tourist destinations.

Spatial elements are important ideas in supporting planning of geotourism destinations. It includes a) tourists generating regions, b) geotourism destinations, c) geotourism areas, d) geotourism service centers (primary, secondary and tertiary), e) route circulation (external and internal), f) gateway (primary and alternative), g) geotourism attractions (primary and secondary), and $h$ ) geotourism routes $[14,15,40]$.

\section{MATERIAL AND METHOD \\ Object Study}

The approach used in this research is qualitative research with primary and secondary data collection. The unit of analysis used in this study consists of five principles in designing tourism destinations (destination physical characteristics; tourism destination study; functional and normative; explanatory and predictive; and integration of spatial elements) and destination spatial elements. This research was conducted for six months in July-November 2018 in Cisolok Geoarea, Ciletuh-Palabuhanratu UGG, Sukabumi Regency. Administratively, Geoarea Cisolok covers three sub-districts, namely Palabuhanratu sub-district, Cikakak subdistrict, and Cisolok sub-district.

\section{Data Collection and Analysis}

Primary data were obtained through field observations at Cisolok Geoarea and semistructured interviews. Secondary data were collected through desk study in the form of spatial information, policy documents, and studies on the development of previous geotourism destinations. Observation activities aim to determine the position of spatial elements based on satellites using Global Positioning System (GPS) technology.

The results of observational data were processed through data collection (coordinate transformation, digitization, and editing), data plotting, and data conversion using geographic information system software (Esri ArcGIS) and graphic design software (Adobe Illustrator). Meanwhile, interviews were conducted with actors directly involved in the development of the Ciletuh-Palabuhanratu UGG, including Ciletuh-Palabuhanratu Geopark Management Agency, Tourism and Culture Office of West Java Province, and Tourism Office of Sukabumi Regency. The scope of the questions in the interview related to the condition of tourism, the direction of tourism development, and tourism management in the Cisolok Region, CiletuhPalabuhanratu UGG. This study uses qualitative analysis methods, map analysis, and descriptive analysis. 


\section{RESULTS AND DISCUSSION}

Cisolok Geoarea generally has an irregular physical condition in the south and hills in the north with an altitude ranging from 0 to $2.960 \mathrm{~m}$ above sea level. These conditions cause the state of the slope is very sloping (more than $35^{\circ}$ ). The types of beaches on the coast of Geoarea Cisolok are coral, rocky, and sandy beaches. The climate in Geoarea Cisolok is affected by a tropical equatorial climate with an average annual rainfall of $2.565 \mathrm{~mm}$ and an average monthly rainfall of $84-376 \mathrm{~mm}$. Cisolok Geoarea has a diversity of natural resources, including marine, coastal, river, and hilly resources. These conditions have the potential for the development of tourism, the existence of new tourism activities, namely adventure tourism that utilizes river flow as rafting attractions. There is an ecological wealth on the coast of Geoarea Cisolok, including terrestrial vegetation ecosystems, mangroves, seaweed, and coral reefs [41].

Socio-cultural diversity as a tourism potential is valuable in improving welfare in Geoarea Cisolok because the culture is in harmony with human values and enhances healthy people's lives and, is an indicator of community welfare. Socio-cultural diversity must be maintained and developed. The existence of natural and sociocultural conditions in Geoarea Cisolok has a close relationship following the development of natural history and culture. Cultural diversity in the Geoarea Clsolok includes Kasepuhan Cipta Gelar, Kasepuhan Sinar Resmi, and Kasepuhan Cipta Mulya. There are annual event celebrations, the Cisolok Fishermen's Party which has been celebrated 20th in 2017, and the election of the Fishermen's Princess as an additional tourist attraction at Cisolok Geoarea.

Identification of the existing tourism resources in Geoarea Cisolok helps in the design of spatial destination models, especially in the cluster of tourist attractions, accessibility, and tourism facilities. The Cisolok Geoarea as a Geotourism Destination was reviewed based on the identification of spatial elements in three sub-districts (Palabuhanratu, Cikakak, and Cisolok) and adjusted to local government policies.

\section{Spatial Elements of Cisolok Geotourism Area}

The design of spatial models in Cisolok Geoarea refers to five fundamental factors that have been identified according to existing conditions. The design includes 1 ) the physical characteristics of the destination, including access availability, road conditions (arterial and collector), and distance and travel time between geotourism attractions; 2) destination study areas through adjustments to the characteristics and structure of each region in Cisolok Geoarea; 3) functional and normative towards the policy integration of spatial planning and tourism plans with the empirical conditions of Cisolok Geoarea; 4) explanatory and predictive about the clarity of the empirical conditions of Cisolok Geoarea in predicting the tourist market, and 5) integration of spatial elements related to the nature and relationship with the tourism component.

Based on these basic references, the design of the spatial model in Cisolok Geotourism Destination includes 11 spatial elements, namely 1) tourist generating regions, 2) geotourism destinations, 3) external route circulation, 4) internal routes circulation, 5) primary gateway, 6) alternative gateway, 7) geotourism area, 8) primary service centers, 9) secondary service centers, 10) Geotourism Attraction (GA), and 11) Supporting Tourist Attraction (STA) (Fig. 1). The spatial elements in the Cisolok Geotourism destination, including:

\section{Tourist generating regions}

Tourists who visit the Cisolok Georoutism Destination, based on physical conditions, come from Jakarta, Banten, Bogor, Sukabumi City, Cianjur, and Bandung.

2. Geotourism destination

Ciletuh-Palabuhanratu UGG consists of three geoareas, namely Cisolok Geoarea, Simpenan Geoarea, and Ciletuh Geoarea. This research is focused on the Cisolok Geoarea as a geotourism destination, covering three administrative subdistricts, namely Cisolok, Cikakak, and Palabuhanratu.

3. External route circulation

The main accessibility for tourists to Cisolok Geoarea can be reached using land transportation via:

a. BOCIMI (Bogor - Ciawi - Sukabumi) toll road, generally tourists from Jakarta, Banten and Bogor.

b. In addition to using private vehicles, tourists from Jakarta, Bogor, and Banten can use public transportation (train) via Jakarta-Bogor-Sukabumi Route.

c. Access tourists from Bandung and surrounding areas via the Purbaleunyi toll road by first passing through Cianjur and Sukabumi City. 


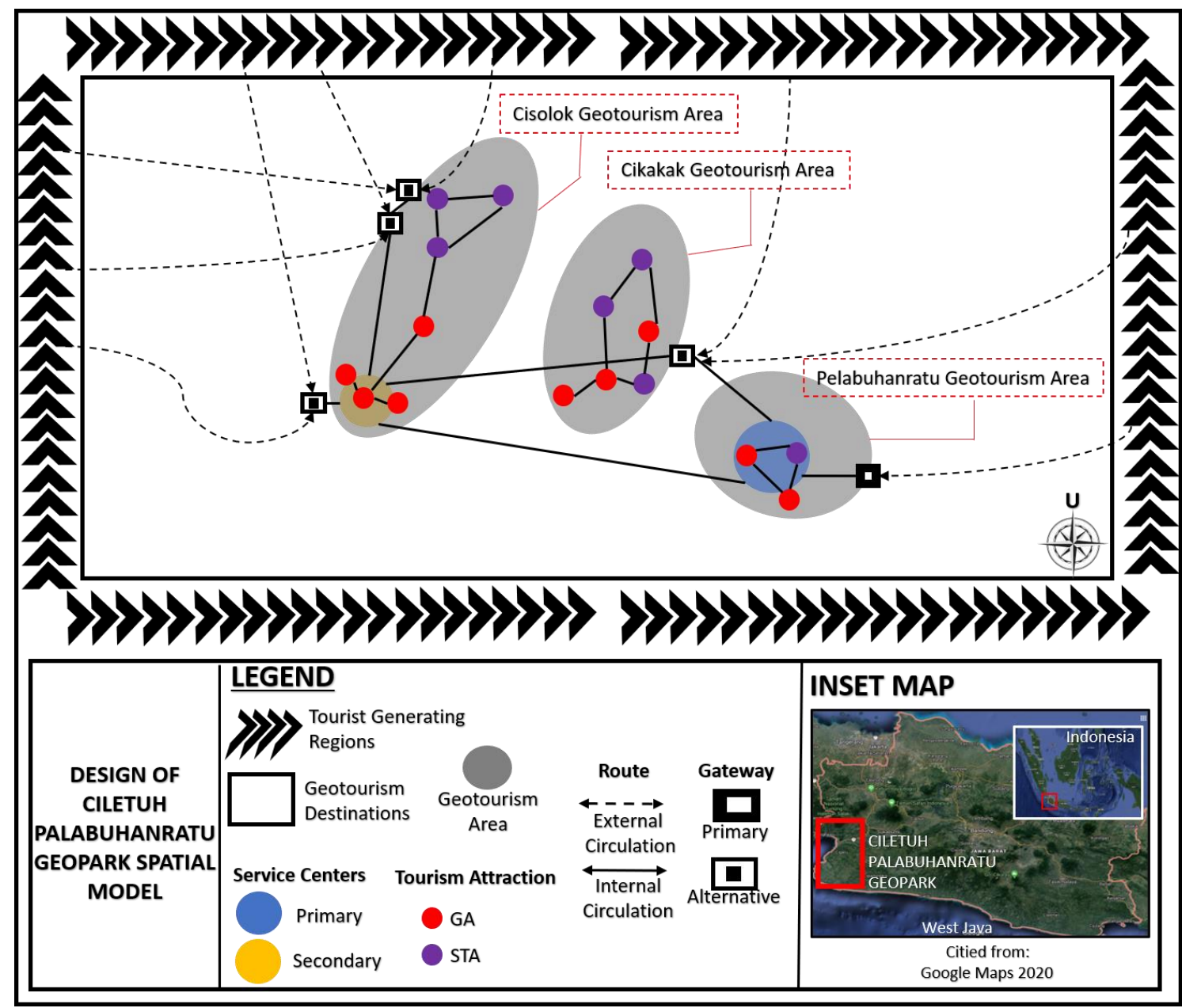

Figure 1. Design of Cisolok Geotourism Destination Spatial Model

4. Internal route circulation

Internal route circulation has a function as a link between the geotourism attractions in the Cisolok Geotourism Destination. Also, internal circulation is accessibility between the gateway to the primary and secondary service centers in Cisolok Geotourism Destination.

5. Primary Gateway

The main entrance or gateway to Cisolok Geotourism Destination is identified via National Road III in Palabuhanratu Subdistrict from the direction of Sukabumi City.

6. Alternative gateway

There are four secondary gateways to Cisolok Geotourism Destination, namely three secondary gateways located in the west (Cisolok Sub-district) and one in the east (Cikakak Sub-district).
7. Geotourism Area

Geotourism area is a grouping of GA and STA. There are three geotourism areas in the Cisolok Geotourism Destination, including Cisolok, Cikakak, and Palabuhanratu.

8. Primary service center

Palabuhanratu Subdistrict is used as the primary service center in the Cisolok Geotourism Destination. It is supported by the existence of facilities and services for tourists. Also, Palabuhanratu sub-district has the function of spreading tourist movements between geoareas.

9. Secondary service center

There is a potential secondary service center located in Cisolok Subdistrict that functions as a spreading geotourism growth and alternative entrance to the western part of the destination. 


\section{Geotourism attraction (GA)}

In total, there are nine GA scattered throughout the Cisolok Geotourism Destination. Two GA (Citepus Beach and Lalay Cave) are in the Palabuhanratu Geotourism Area; three GA (Cimaja Beach, Sukawayana Lava, and Cikakak Hill) are in the Cikakak Geotourism Area; and four GA (Habiebie Hill, Cibangban Beach, Karang Hawu Beach, and Geyser Hill) are located in the Cikakak Geotourism Area.

11. Supporting tourism attraction (STA)

A total of seven STAs are scattered throughout Cisolok Geotourism Destination. Six STAs based on cultural diversity are scattered in the Cikakak Geotourism Area (Pangguyangan Site, Tangkil Mountain Site, and Cangkuk Site) and Cisolok Geotourism Area (Kasepuhan Sinarresmi, Kasepuhan Ciptamulya, and Kasepuhan Ciptagelar). Meanwhile, there is one STA based on nature that is Tangkubanparahu Nature Reserve in Palabuhanratu Geotourism Area.

\section{Concentration-Dispersal Strategy in Cisolok Geotourism Area}

The implementation of the ConcentrationDispersal strategy in Cisolok Geoarea aims to reduce pressure on primary service centers in Palabuhanratu through spreading tourist movements to the secondary service center at Cibangban Beach, Cisolok. Current conditions, tourism activities are concentrated in the Area of Palabuhanratu Geotourism, efforts to spread tourists play a role in avoiding potential overtourism, disseminating tourism income, increasing competitiveness through exploration, and diversification of tourist attractions. The activity of spreading tourist movements has the potential to create jobs and income distribution. The application of the spatial model of Destination Geotourism in Cisolok Geoarea is shown in Figure $2[42,43]$.

The main objective of the concentrationdispersal strategy in this study has relevance to that in previous studies, including to reduce pressure on the core area and spread income from tourism. Tourism activities in Palabuhanratu have beem developed before the Geopark

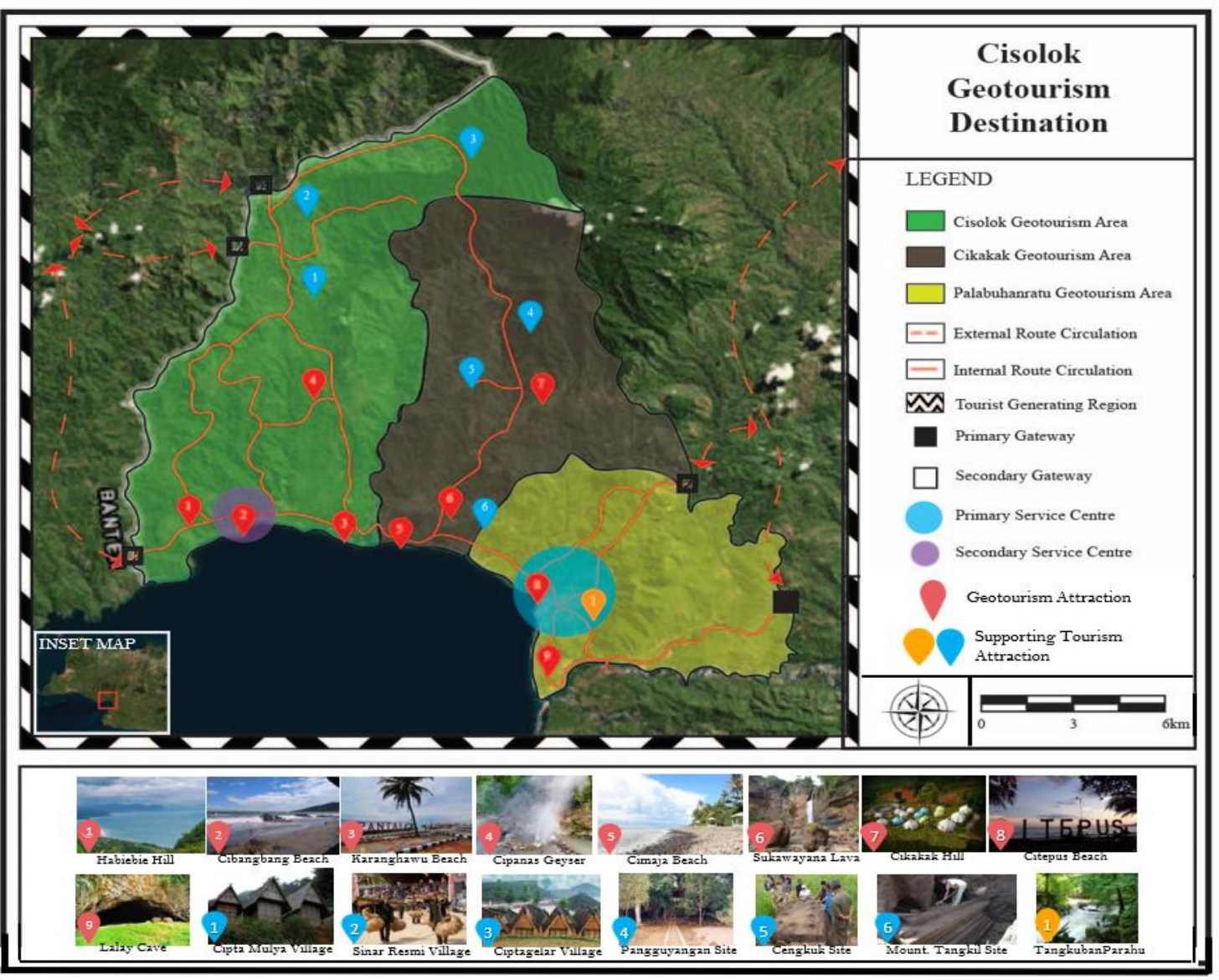

Figure 2. Application of Cisolok Geotourism Area Spatial Model 
existed. Factors of tourist attraction, ease of accessibility, and availability of facilities for tourists such as hotels and restaurants are the reasons for the concentration of tourists in Palabuhanratu. The spread of tourists from Palabuhanratu directed to the Cibangban Beach Area, Cisolok, in addition to the potential to reduce overtourism is also a tool for income distribution. The presence of tourists provides new opportunities for entrepreneurs and creates jobs in Cisolok and Cikakak Geotourism Area. Encouraging tourists to explore the periphery of the destination can stimulate the economy in these areas [14-16].

The distribution-concentration strategy is also designed to increase the attractiveness and competitiveness of Cisolok geotourism destinations by presenting new features to tourists. It needs to be supported by marketing programs to increase the length of stay and total expenditure. In 2019, there were 2.5 million tourists who visited Ciletuh-Palabuhanratu UGG. The number has exceeded the original target of 1 million tourists. The high number of tourist visits to Ciletuh-Palabuhanratu UGG is inversely proportional to the income obtained. Only IDR 273 million was the revenue for the local government, which is very far from the set target of IDR 1.3 billion $[44,45]$. It is allegedly due to a leak from the tourist arrival route to CiletuhPalabuhanratu UGG. In response, the Regent of Sukabumi encouraged the development of thematic tourism by increasing the potential of villages in Cisolok Regency to be used as tourist villages [46].

These steps encourage integrated tourism products in Cicolok geotourism destinations. This step is classified as a visitor management strategy in response to problems at the destination, including differences in development, congestion, and failure to control visitor behaviour [6]. In this study, the concentration-dispersal strategy in the Cisolok Geotourism Area can also be a tool to prevent leakage of tourist arrivals [47]. This strategy is carried out through a spatial approach by considering space and time.

The intended space and time are geographical distances related to the time and distance required from tourist generating regions to the Cisolok Geotourism Area. The spatial aspect is one of the important aspects because it can influence the travel patterns of tourists in a destination [48]. In this case, tourism planners and decision-makers must design internal and external circulation routes to Cisolok Geotourism destinations that are supported by accessibility [49]. Each route is directed to have a diversity of tourist themes to attract tourists [47].

In Figure 2, the potential of GA and STA is classified as a theme of cultural and coastal tourism areas, according to the Cisolok Natural Tourism Area. The establishment of the Cisolok Region as a Geotourism Destination through a concentration-dissemination strategy is expected to create a new gateway, a new staging area, and the grouping of new tourist attractions with Cibangban Beach is a primary tourist attraction because of its accessibility. Ironically, GA Cibangbang is not included in the CiletuhPalabuhanratu GA UGG directory. Instead, GA Cibangban fulfills GA criteria with geological processes, forms, tourism activities, basic knowledge related to geological phenomena, geohistory, and also Geo + (legend or ancient folklore local and origin of the occurrence of a place) [37].

Previous research has applied visitor management strategies through education, geotourism interpretation programs, and involving local communities. This research has a novelty in visitor management strategies implemented in Ciletuh-Palabuhanratu UGG through a spatial approach. The implementation of the Concentration-Dispersal Strategy is expected to contribute to environmental sustainability and economic equality at the Ciletuh-Palabuhanratu UGG.

\section{CONCLUSION}

The Cisolok Geoarea has 11 spatial elements. The Concentration-Dispersal Strategy is applied to the Cisolok Geotourism Destination to reduce pressure on primary service centers of Palabuhanratu Geotourism Area by spreading tourists to potential secondary service centers (Cisolok Geotourism Area, especially in Cibangban Beach) to equalize people's income, reduce the risk of over-tourism and diversify products to potential the competitiveness of Ciletuh Palabuhanratu UGG.

There are several suggestions for further research, including geotrail development of the Cisolok Geotourism Destination, planning interpretation along the geotrail, development of community based geotourism, mitigation system planning, marketing planning, and tourism zoning planning for the construction of a secondary service center in Cisolok Geotourism Area, especially on Cibangban Beach. 


\section{REFERENCES}

[1] Farsani, N. T., C. O. A. Coelho, C. M. M. Costa, A. Amrikazemi. 2014. Geo-knowledge Management and Geoconservation via Geoparks and Geotourism. Geoheritage 6(3), 92-185.

[2] Gordon, J. E. 2018. Geoheritage, geotourism and the cultural landscape: Enhancing the visitor experience and promoting geoconservation. Geoscience 8(4), 136.

[3] Henriques, M. H. and J. Brilha. 2017. UNESCO Global Geoparks: A strategy towards global understanding and sustainability. Episodes 40(4), 55-349.

[4] Newsome, D. and R. Dowling. 2018 Geoheritage and geotourism. Geoheritage: assessment, protection, and management. In: Reynard, E. and J. Brilha. Geotourism and Geoheritage, 305-321. DOI: 10.1016/B978-012-809531-7.00017-4.

[5] Han, J., F. Wu, M. Tian, and W. Li. 2018. From geopark to sustainable development: heritage conservation and geotourism promotion in the Huangshan UNESCO Global Geopark (China). Geoheritage 10(1), 79-91.

[6] Dowling, R. K., D. Newsome. 2018. Geotourism destinations - visitor impacts and site management considerations. Czech Journal of Tourism 6(2), 29-111.

[7] Farsani, N. T., C. Coelho, and C. Costa. 2011. Geotourism and geoparks as novel strategies for socio-economic development in rural areas. International Journal of Tourism Research 13(1), 68-81. DOI: 10.1002/jtr.800.

[8] Stoffelen, A. and D. Vanneste. 2015. An integrative geotourism approach: bridging conflicts in tourism landscape research. Tourism Geographies 17(4), 60-544.

[9] Ernawati, N. M., I W. B. Arjana, and A. A. R. Sitawati. 2019. Tourist accomodation : a hosttourist matched for Batur Geotourism. Journal of Indonesian Tourism and Develpment Studies 7(2), 74-82.

[10] Hakim, L., M. Soemarno. 2017. Biodiversity conservation, community development and geotourism development in Bromo-TenggerSemeru-Arjuno biosphere reserve, East Java. Geojournal and Tourism and Geosites 20(2), 30-220.

[11] Yuliawati A. K., K. N. Pribadi, M. S. D. Hadian. 2016. Geotourism resources as part of sustainable development in Geopark Indonesia. In: Proceedings of the 2016 Global Conference on Business, Management and Entrepreneurship. Atlantis Press. Bandung.
[12] Muslim, D., E. Haerani, F. N. Muslim, G. O. Muslim. 2019. Toward the safe live-able built environment around Ciletuh-Palabuhanratu Geopark Area in Sukabumi Regency, Indonesia. IOP Conference Series: Earth and Environment Science 248(1), 012036.

[13] UNESCO. 2016. UNESCO Global Geoparks. Celebrating earth heritage, sustaining local communities. France.

[14] Meyer, D. 2004. Tourism routes and gateways : key issues for the development of tourism routes and gateways and their potential for pro-poor tourism. ODI Overseas Development Institute. 1-31.

[15] Dredge, D. 1999. Destination place planning and design. Annals of Tourism Research 26(4), 91-772.DOI:10.1016/S0160-7383(99)00007-9.

[16] Weaver, D. B. 2006. Sustainable tourism: theory and practice. Elsevier ButterworthHeinemann. Amsterdam; Boston.

[17] Piskóti, I. and K. Nagy. 2016. Route-Based tourism product development as a tool for social innovation: history valley in the Cserehát Region. Theory, Methodology, Practice 12(2), 75-86.

[18] Roberts, L. and D. Hall. 2001. Rural tourism and recreation: Principles to practice. CABI.

[19] Brown, K., R. K. Turner, H. Hameed, I. Bateman. 1997. Environmental carrying capacity and tourism development in the Maldives and Nepal. Environmental Conservation 24(4), 316-325.

[20] Groen, L., A. Niemann, and S. Oberthür. 2012. The EU as a global leader? The Copenhagen and Cancún UN climate change negotiations. Journal of Contemporary European Research 8(2), 173-191.

[21] Torres, R. 2002. Cancun's tourism development from a Fordist spectrum of analysis. Tourist Studies 2, 87-116.

[22] Inskeep, E. and M. Kallenberger. 1992. An integrated approach to resort development. World Tourism Organization. Madrid.

[23] Weaver, D. and L. Lawton. 2014. Tourism management, $5^{\text {th }} \mathrm{Ed}$. Wiley.

[24] Inskeep, E. 1988. Tourism planning: An emerging specialization. Journal of the American Planning Association 54(3), 72-360.

[25] Helgadóttir, G. and I. Sigurđardóttir, 2018. The riding trail as geotourism attraction: Evidence from Iceland. Geosciences 8(10), 376. DOI: $10.3390 /$ geosciences8100376.

[26] Getz, D. 1986. Models in tourism planning. towards integration of theory and practice. Tourism Management 7(1), 21-32. 
[27] Saluja, V. and S. Anand. 2017. Land use and land cover change in first proposed national geopark, Varkala in Kerala, India. International Journal of Geoheritage 5(2), 3442.

[28] Ginting, N., N. V. Rahman, G. Sembiring. 2017. Tourism development based on geopark in bakkara Caldera Toba, Indonesia. IOP Conference Series: Material Science and Engineering 180(1), 12086.

[29] Rahman, N. V., N. Ginting, S. Subhilhar, and N. Narisa. 2018. Planning a tourism landscape in geosite area: Sipiso-piso waterfall. IOP Conference Series: Earth and Environmental Science 126(1), 12196.

[30] Ali, C. A. and T. Unjah. 2011. The importance of geological heritage resources in land use planning: Experience from Langkawi Geopark. Plan Malaysia 9(1), 55-82.

[31] Aziz, S., H. S. Hashim, T. Unjah, R. A. Aziz, C. K. L. Geraldine. 2011. Land use planning statutes for Langkawi Geopark conservation and development. Plan Malaysia 9(1), 83-102.

[32] Powell, R. B., T. F. Green, P. J. Holladay, K. E. Krafte, M. Duda, M. T. Nguyen, et al. 2018. Examining community resilience to assist in sustainable tourism development planning in Dong Van Karst Plateau Geopark, Vietnam. Tourism Planning and Development 15(4), 57436. DOI: $10.1080 / 21568316.2017 .1338202$

[33] Wulung, S. R. P., A. K. Yuliawati, M. S. D. Hadian. 2019. Geotourism potential analysis of North Kalimantan. In: $3^{\text {rd }}$ International Seminar on Tourism (ISOT 2018) Atlantis Press. Bandung. Advances in Social Science, Education and Humanities Research, 259.

[34] Permadi, R. W. A., M. S. D. Hadian, Y. Yustikasari, A. Nugraha, S. R. P. Wulung. 2019. Inventarisasi potensi geowisata di Provinsi Kalimantan Utara. Media Bina IImiah 14(4), 2513-2520.

[35] Mehmood, F., S. Ahmad, and D. H. Kim. 2019. Design and development of a real-time optimal route recommendation system using big data for tourists in Jeju Island. Electronics 8(5), 506.

[36] Jeon, Y., J. G. Koh, J. S. Ki, and S. Lee. 2016. A case study on the geotrail revitalization in the Jeju Island Geopark. Journal of the Geological Society of Korea 52(5), 38-527.

[37] Wulung, S. R. P. and B. Brahmantyo 2019. Geotourism reinterpretation towards natural tourist attractions in Bandung Basin, West Java, Indonesia. In: $3^{\text {rd }}$ International Seminar on Tourism (ISOT 2018). Atlantis Press.
Bandung. 278-282. Advances in Social Science, Education and Humanities Research 259.

[38] Wulung, S. R. P. 2018. Spatial Model analysis of Bandung Basin Geotourism Destination. Bandung Institute of Technology. Bandung.

[39] Wulung, S. R. P., Y. Adriani, B. Brahmantyo, and A. Rosyidie. 2019. Geotourism in West Bandung Regency to promote CitatahSaguling Aspiring Geopark. In: The $3^{\text {rd }}$ International Geography Seminar 2019.

[40] Gunn, C. A., T. Var 2002. Tourism planning: basics, concepts, cases. $4^{\text {th }} \mathrm{Ed}$. Routledge. New York.

[41] Wahyudin, Y. 2011. Karakteristik sumberdaya pesisir dan laut kawasan Teluk Palabuhanratu, Kabupaten Sukabumi, Jawa Barat. Bonoworo Wetlands 1(1), 19-32.

[42] UNESCO. 2020. Gallery: CiletuhPalabuhanratu Geopark Indonesia. Available at: https://en.unesco.org/galleries/ciletuhpalabuhanratu-geopark-indonesia.

[43] Yunita, N. W. 2019. 10 tempat wisata di Geopark Ciletuh, surga tersembunyi di Sukabumi. detikTravel.

[44] Christiyaningsih. 2019. Semester 1 2019, 2,5 Juta Wisatawan Kunjungi Sukabumi. Available at: https://nasional.republika.co.id/berita/ nasional/daerah/ptakel459/semester-1-201925-juta-wisatawan-kunjungi-sukabumi.

[45] Egi. 2019. 6 bulan terakhir Sukabumi dikunjungi 2,5 juta wisatawan, 5 fakta warganet mesti tahu. Available at: http://sukabumixyz.com/2019/06/19/6bulan-terakhir-sukabumi-dikunjungi-25-jutawisatawan-5-fakta-warganet-mesti-tahu/.

[46] Public Relation of Sukabumi Regency. 2019. Kembangkan wisata baru, $H$. Marwan Hamami lakukan Saba Desa Pariwisata Available at: https://sukabumikab.go.id/ portal/berita-daerah/2836/kembangkanwisata-baru-hmarwan-hamami-lakukan-sabadesa-pariwisata.html.

[47] Pattanaro, G. and F. Pistocchi. 2016. Linking destinations through sustainable cultural routes. SYMPHONYA Emerging Issues in Management 1, 83-96.

[48] Miossec, J. M. 1977. Un modèle de l'espace touristique. Espace Geographique 6(1), 41-48.

[49] Miossec, J. M. 1976. Espace Et Pouvoir: La localisation des forces de décision dans le monde: esquisse de géographie politique théorique. Espace Geographique 5(3), 75-165. 